\title{
HUBUNGAN PEMERINTAH PUSAT DAN PEMERINTAH DAERAH: KAJIAN MENGENAI OTONOMI KHUSUS DI PROVINSI ACEH
}

\author{
Yeni Sri Lestari \\ Sosiologi, Fakultas Ilmu Sosial dan Ilmu Politik, Universitas Teuku Umar \\ yenilestari24@yahoo.com
}

\begin{abstract}
The prolonged conflict in Aceh between the central government and the Free Aceh Movement (GAM) and the earthquake and tsunami disaster in Aceh have added to the long list of dark history of the suffering of the Acehnese people. The peaceful decision agreed upon by the central government with the Aceh government which gave birth to special autonomy in Aceh provided fresh space for improving relations between the two governments. However, the space of freedom that is given is not fully able to control and build good relations easily, because there are still some differences in principles and political views between the central government and the Aceh government so that conflicts still arise. Therefore, this article aims to examine whether the provision of special autonomy will ensure the existence of Aceh remains within the NKRI?, how is the development of the Central Government's cooperation with the Aceh Government?, What are the impacts of special autonomy in Aceh?. This study found that the special autonomy acquired by Aceh sufficiently guaranteed the authority of the Aceh government in regulating its own regional affairs in accordance with the life principles of the Acehnese people, this was inseparable from the ongoing efforts and efforts between the central government and the Aceh government in establishing cooperation for the integrity of the nation. Special autonomy in Aceh provided its own dynamics for the political stability and stability of the Acehnese people.
\end{abstract}

Keywords: Central government, Aceh government, special autonomy

\begin{abstract}
ABSTRAK
Konflik berkepanjangan di Aceh antara pemerintah pusat dengan Gerakan Aceh Merdeka (GAM) serta musibah gempa dan tsunami di Aceh telah menambah daftar panjang sejarah kelam penderitaan masyarakat Aceh. Keputusan damai yang disepakati oleh pemerintah pusat dengan pemerintah Aceh yang melahirkan otonomi khusus di Aceh memberi ruang segar bagi perbaikan hubungan antara kedua pemerintahan tersebut. Namun, ruang kebebasan yang diberikan tidak sepenuhnya mampu mengontrol dan membangun hubungan baik dengan mudah, dikarenakan masih terdapat beberapa
\end{abstract}


perbedaan prinsip dan pandangan politik antara pemerintah pusat dan pemerintah Aceh sehingga masih memungkinkan timbulnya konflik. Oleh karena itu, artikel ini bertujuan untuk mengkaji mengenai apakah dengan diberinya otonomi khusus akan menjamin keberadaan Aceh tetap dalam NKRI?, bagaimanakah perkembangan kerjasama Pemerintah Pusat dengan Pemerintah Aceh?, apakah dampak dari otonomi khusus di Aceh?. Kajian ini mendapati bahwa otonomi khusus yang diperoleh Aceh cukup menjamin kewenangan pemerintah Aceh dalam mengatur urusan daerahnya sendiri sesuai dengan prinsip hidup masyarakat Aceh, hal ini tidak terlepas dari upaya dan usaha yang terus dilakukan antara pemerintah pusat dan pemerintah Aceh dalam menjalin kerja sama bagi keutuhan bangsa. Otonomi khusus di Aceh memberikan dinamika tersendiri bagi kestabilan politik dan kemapanan masyarakat Aceh.

\section{Kata Kunci: Pemerintah pusat, pemerintah Aceh, Otonomi khusus}

\section{PENDAHULUAN}

Indonesia adalah negara demokratis yang terdiri dari kepulauan dengan sistem negara kesatuan, yaitu Negara Kesatuan Republik Indonesia. Indonesia menganut sistem pemerintahan presidensial, dimana presiden merupakan kepala negara dan kepala pemerintahan. Dalam menjalankan tugasnya presiden dibantu oleh wakil presiden dan para menteri yang mengurusi bidang-bidang tertentu dalam perlembagaan publik di Indonesia, sedangkan di daerah tingkat provinsi, presiden dibantu oleh kepala daerah yang disebut gubernur.

Indonesia menganut sistem desentralisasi dalam pembagian kekuasaan dari pusat ke daerah. Bagian dari desentralisasi di Indonesia dikenal dengan otonomi daerah, yaitu daerah-daerah di Indonesia memiliki kewenangan tersendiri untuk mengurus dan mengatur rumah tangga daerahnya. Sistem pemerintahan daerah ini tertuang dalam Undang-undang Nomor 23 Tahun 2014 tentang Pemerintahan Daerah.

Otonomi daerah di Indonesia lahir sebagai akibat dari kegagalan Pemerintah Indonesia mengantisipasi gejala krisis ekonomi dan keuangan global pada tahun 1998, dikarenakan Pemerintah Pusat lebih banyak menggunakan waktu dan energinya untuk mengurusi masalah-masalah domestik yang sebenarnya dapat diurus oleh pemerintah daerah. Pola hubungan pusat-daerah yang paternalistik harus diubah menjadi pola hubungan yang bersifat kemitraan dan desentralistik, maka lahirlah Undang-undang pertama tentang pemerintahan daerah yaitu Undang-undang Nomor 22 Tahun 1999 (Syamsuddin Haris, 2007).

Daerah di Indonesia memiliki dasar dalam pengurusan rumah tangga daerahnya berdasarkan UU tentang Pemerintahan Daerah yang telah ditetapkan oleh Negara, sehingga daerah di Indonesia merupakan daerah otonom. Sebagai daerah otonom, 
daerah-daerah di Indonesia berhak untuk membuat Peraturan Daerah (Perda) sebagai dasar pelaksanaan pemerintahan daerah di masing-masing daerah yang kedudukannya berada di bawah Undang-undang, sehingga setiap Perda tidak boleh bertentangan dengan Undang-undang.

Provinsi Aceh sebagai salah satu daerah otonom di Indonesia, memiliki kekhususan dalam penyelenggaraan pemerintahan daerah atau dikenal dengan otonomi khusus. Hal ini dikarenakan Provinsi Aceh sebagai daerah bekas konflik yang pernah distatuskan sebagai Daerah Operasi Militer (DOM) akibat adanya aktifitas separatisme dari golongan Gerakan Aceh Merdeka (GAM) serta akibat terjadinya musibah gempa dan tsunami pada 2004 silam.

Upaya pemerintah pusat untuk tetap mempertahankan Aceh sebagai salah satu daerah di Indonesia dengan berbagai cara telah ditempuh, penderitaan yang berkepanjangan dirasakan oleh rakyat Aceh baik ketika DOM dan ditambah dengan musibah tsunami menyadarkan kedua belah pihak (Pemerintah Indonesia dan GAM) untuk menyudahi konflik di Aceh, sehingga melalui perjanjian damai Memory of Understanding (MoU) Helsinki disepakati oleh Pemerintah Pusat dan GAM untuk berdamai dalam payung NKRI.

Kesepakatan damai yang telah tercipta tidak menjadikan hubungan antara keduanya selalu harmonis. Terdapat perbedaan yang seringkali menjadi penghambat terjalinnya keharmonisan antara pusat dan Aceh dikarenakan iklim perdamaian yang belum sepenuhnya terbangun memicu rasa sentimen kedua nelah pihak, namun pembiaraan terhadap hal ini dapat menganggu perdamaian yang telah terjalin. Pentingnya pembangunan pondasi kerja sama antara pusat dan Aceh untuk menjaga persatuan dan kesatuan menjadi catatan tersendiri bagi bangsa ini. Oleh karena itu, penting dilakukan kajian untuk melihat sejauh mana hubungan pemerintah pusat dengan pemerintah Aceh dalam mengimplementasikan pelaksanaan otonomi khusus.

\section{TINJAUAN PUSTAKA}

\subsection{Desentralisasi}

Desentralisasi adalah azas penyelenggaraan pemerintahan yang dipertentangkan dengan sentralisasi. Desentralisasi menghasilkan pemerintahan lokal (local government). Adanya pembagian kewenangan serta tersedianya ruang gerak yang memadai untuk memaknai kewenangan yang diberikan kepada unit pemerintahan yang lebih rendah (pemerintah lokal), merupakan perbedaan terpenting antara konsep desentralisasi dan sentralisasi (Syamsuddin Haris, 2007).

Desentralisasi memberikan sepenuhnya pembahagiaan kekuasaan daripada pusat untuk daerah dalam segala aspek kecuali hal-hal yang menjadi urusan pusat seperti kebijakan fiskal dan moneter, pertahanan, keagamaan, hubungan luar negeri, peradilan dan segala bidang yang bersifat strategis nasionalis. Sedangkan sistem sentralisasi lebih 
menitikberatkan segala urusan negara terpusat hanya kepada pemerintah pusat saja tanpa memberikan keleluasaan bagi daerah dalam mengatur daerahnya sendiri.

Pengelolaan hubungan pusat-daerah ke arah yang lebih harmonis serta memenuhi aspirasi kedua pihak secara adil dan proporsional bukanlah persoalan yang mudah. Perjalanan sejarah bangsa Indonesia sendiri memperlihatkan tingginya tingkat fluktuasi konflik dan ketegangan dalam relasi pusat dan daerah meskipun berbagai upaya penyelesaian telah dilakukan sejak periode 1950-an hingga era reformasi dewasa ini. Agenda penyelesaian yang ditawarkan pemerintah pusat hampir selalu bermuara pada munculnya persoalan baru yang tidak atau kurang diantisipasi dan diakomodasi dalam proposal kebijakan sebagai akibat dari besarnya kepentingan elit politik Jakarta untuk mempertahankan posisi superior dan dominasi pusat atas daerah (Syamsuddin Haris, 2007).

Konflik Aceh yang berkepanjangan hingga terjadinya musibah tsunami pada tahun 2004 silam memberikan peluang bagi pemerintah pusat dan GAM untuk samasama menyudahi konflik yang menyebabkan penderitaan yang berkepanjangan pada masyarakat Aceh dan ditambah dengan musibah tsunami yang juga banyak memakan korban jiwa. Ditandatanganinya perjanjian MoU Helsinki di Finlandia memberikan titik terang bagi penegakkan demokrasi yang seutuhnya di Aceh.

Undang-undang otonomi daerah memberikan perspektif baru dalam mengamalkan prinsip otonomi daerah, sehingga daerah memiliki otonomi penuh, luas dan bertanggung jawab dalam mengatur daerahnya sendiri. Dinamika otonomi daerah ini bertujuan untuk meningkatkan kinerja daerah dalam memberikan pelayanan, mengamalkan asas-asas demokrasi serta pelaksanaan pembangunan daerah yang berkesinambungan terhadap kemakmuran dan kesejahteraan masayrakat di daerah. Sehingga hubungan antara pemerintah pusat dan pemerintah daerah terjalin secara seimbang dan mencapai kesepakatan bagi kedua belah pihak dalam merumuskan indikator keberhasilan di daerah.

Kebijakan undang-undang mengenai otonomi daerah sudah lama muncul di Indonesia, dimulai dengan Undang-undang Nomor 5 Tahun 1974, namun UU ini lebih kepada praktek sentralisasi bukan desentralisasi, maka semenjak reformasi mulai disahkan Undang-undang Nomor 22 tahun 1999 yang mulai mengatur tentang sistem desentralisasi di Indonesia, Undang-undang Nomor 32 Tahun 2004 tentang otonomi daerah mulai secara tegas mengatur prinsip-prinsip pembagiaan kekuasaan dari pusat kepada daerah, yang kemudian direvisi kembali menjadi Undang-Undang Nomor 23 Tahun 2014.

Aceh melalui perjanjian damai MoU Helsinki diberikan kekuasaan menjadi daerah otonomi khusus yang ditetapkan dengan Undang-undang Nomor 11 tahun 2006 yang mengatur mengenai segala urusan daerah Aceh beserta kekhususannya. Lahirnya UUPA ini menjadi salah satu penyelesaian konflik kepentingan yang selalu ada antara Pemerintah Pusat dengan Pemerintah Aceh, dimana Aceh selalu menganggap 
Pemerintah Pusat berperan dominan dalam mengurusi Sumber Daya Alam (SDA) yang melimpah di Aceh, namun dengan hadirnya UUPA memberikan pembagian yang tegas antara kewenangan pusat dan daerah Aceh dalam mengelola SDA yang ada di Aceh.

Reformasi desentralisasi mensyaratkan adanya reformasi dalam hubungan pusat dan daerah disertai otonomi pemerintahan daerah. Ketika pemerintah daerah dan masyarakat lokal mencapai tingkatan otonomi, keduanya dapat memberdayakan sumber daya lokal demi mencapai taraf pembangunan ekonomi yang tinggi di daerahnya masing-masing. Selanjutnya, apabila desentralisasi tidak dilihat sebagai tujuan bagi dirinya sendiri, maka desentralisasi bisa menciptakan pemerintahan daerah yang terbuka, responsif dan efektif serta mampu memperluas sistem representasional dalam membuat keputusan bagi kepentingan masyarakat (Muhammad Noor, 2012: 6).

Wujud keadilan dalam sistem otonomi daerah di Aceh dapat diwujudkan dengan baik apabila pemerintah daerah Aceh, DPRA dan DPD Aceh yang merupakan keterwakilan rakyat dalam suatu pemerintahan dan parlemen mampu mengaplikasikan aspirasi rakyat dalam setiap kebijakan yang dibuat seperti membentuk qanun yang mencakup kesejahteraan dan kemakmuran masyarakat Aceh dan kebijakan itu tidak melangkahi kepentingan pemerintah pusat, dalam artian, Aceh sebagai daerah otonomi khusus yang memiliki hak-hak istimewa didalamnya janganlah menggunakan hak tersebut untuk membentuk suatu kebijakan yang bertentangan dengan kepentingan pusat atau membuat kepentingan yang menjurus kepada perpecahan yang akan menyebabkan konflik, hubungan pusat dan pemerintah Aceh harus bertujuan untuk membangun reformasi desentralisasi sesuai dengan kepentingan masyarakat banyak.

Otonomi daerah sangat kondusif bagi terjadinya konflik. Kebebasan yang menyertai otonomi seringkali ditafsirkan sebagai kesempatan untuk mengembangkan diri dengan mengelola sumber daya alam dan sumber daya manusia menurut kepentingan sendiri yang merupakan sumber konflik yang amat potensial di masa-masa mendatang. Otonomi daerah hanyalah dapat berjalan dengan baik bila ada pemahaman yang baik terhadap kebebasan dan kewenangan daerah, disamping adanya kemampuan mengendalikan diri dalam menjalanan kebebesan (Syamsuddin Haris, 2007).

Otonomi khusus yang diberikan kepada Aceh harus digunakan sebaik mungkin demi peningkatan kesejahteraan dan kemakmuran masyarakat Aceh, bukan lagi digunakan sebagai kepentingan individu atau kelompok tertentu dalam meraih keinginan yang akan menyebabkan penderitaan kepada masyarakat Aceh lagi. Hal ini dapat diwujudkan dengan menjaga hubungan yang harmonis serta komunikasi yang baik antara pemerintah pusat dan pemerintah Aceh, serta sama-sama tetap menjalankan isi perjanjian MoU Helsinki sesuai dengan yang termaktub dalam perjanjian tersebut.

Sistem desentralisasi secara luas tidak hanya mengatur hubungan antara pemerintah pusat dengan pemerintah daerah saja, namun juga mengatur hubungan dengan agen-agen otonom lain seperti Lembaga Swadaya Masyarakat (LSM), sektor privat, perusahaan publik, dll. Hal ini dapat dilihat seperti dalam bagan berikut: 
Bagan 2.1. Desentralisasi Tanggung Jawab dari Pemerintah Pusat

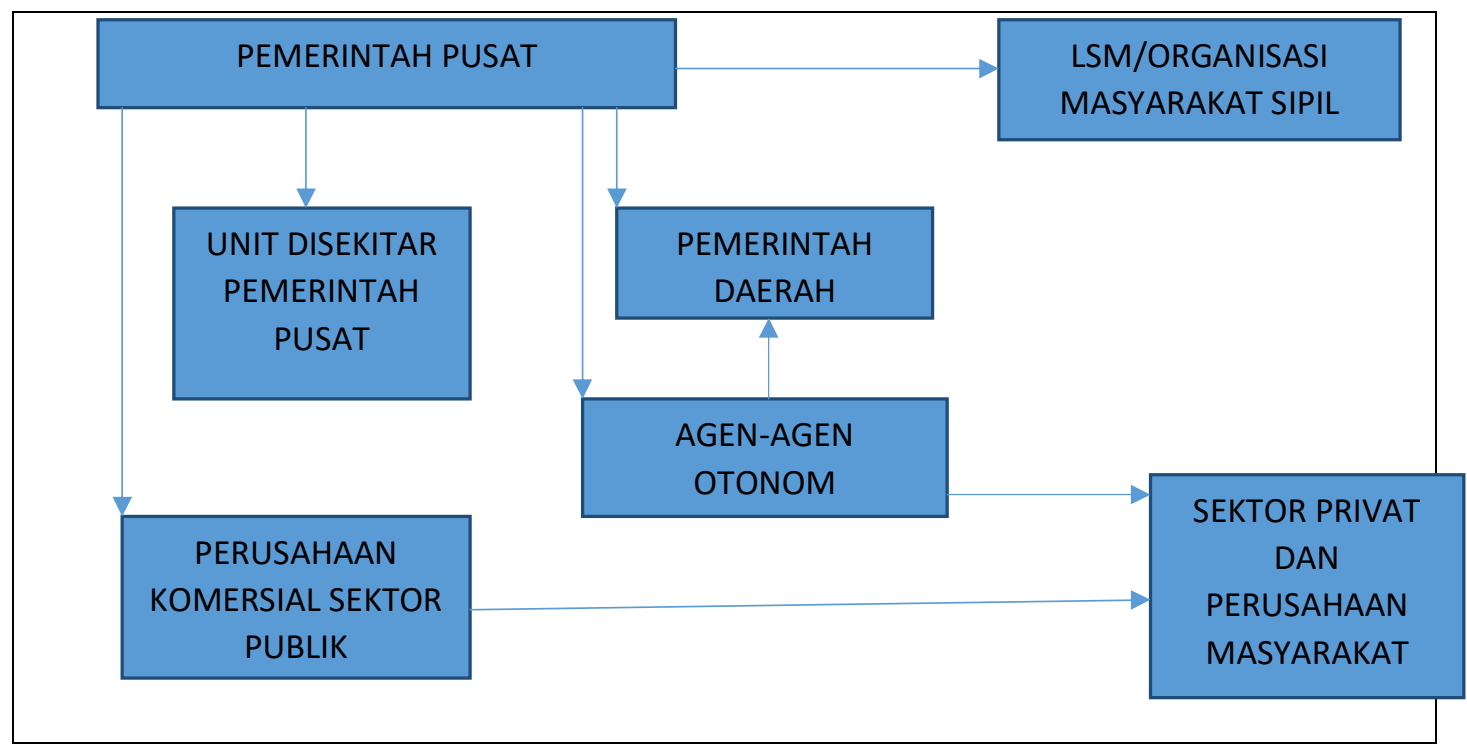

Sumber: Muhammad Noor, 2012: 14

Pelaksanaan asas desentralisasi yang meliputi berbagai sektor memberikan dorongan bagi terjadinya reformasi sektor publik yang menjamin pembangunan pelayanan masyarakat lebih efektif dan efisien. Oleh karena itu, desentralisasi diharapkan mampu untuk menjadi semangat bagi daerah dalam mewujudkan reformasi birokrasi yang menjadi landasan utama keberhasilan dalam penyelenggaraan pemerintahan suatu daerah.

\subsection{Otonomi Khusus Aceh}

Asas desentralisasi dibagi dalam 2 kategori yaitu desentralisasi simetris dan desentralisasi asimetris atau diartikan sebagai otonomi khusus. Menurut Joachim Wehner, otonomi yang berbeda tersebut merupakan hal yang wajar dalam praktik penyelenggaraan pemerintahan di banyak negara. Hal tersebut berlangsung baik dalam negara kesatuan yang desentralisasikan maupun negara yang menganut sistem federatif (Malahayati, 2015: 21).

Pemerintahan daerah di Aceh dijalankan sesuai dengan sistem ketatanegaraan yang memiliki sifat khusus atau istimewa sebagai gambaran karakter khas sejarah perjuangan rakyat Aceh yang memiliki daya juang dan ketahanan tinggi dalam menjaga keutuhan dan persatuan daerahnya. Karakter khas ini bersumber kepada pandangan hidup yang dilandaskan pada prinsip syari'at Islam yang melahirkan budaya Islam yang kuat sebagai modal perjuangan dalam mempertahankan dan menjaga kemerdekaan Indonesia. 
Pengadopsian model disentralisasi asimetris didasarkan pada kebutuhan akan kerangka administrasi yang handal dalam mengelola keragaman lokal. Format pengorganisasian negara dilihat sebagai wujud responsif atas realitas keberagaman masyarakat sebagai sumber input bagi bekerjanya sistem politik dan pemerintahan (Muhammad Fauzan, 2006: 44). Perbedaan antara disentralisasi simetris dengan disentralisasi asimetris dapat dilihat pada bagan berikut:

\section{Bagan 2.2. Perbedaan Antara Otonomi daerah dan Otonomi Khusus}

\begin{tabular}{|c|c|c|c|}
\hline No. & Aspek & Otonomi Daerah & Otonomi Khusus \\
\hline 1. & Dasar berlakunya & $\begin{array}{l}\text { Kewenangan yang berlaku } \\
\text { untuk semua daerah di suatu } \\
\text { negara karena adanya } \\
\text { peralihan dari sistem } \\
\text { sentralistik menuju sistem } \\
\text { desentralisasi }\end{array}$ & $\begin{array}{l}\text { Kewenangan yang tidak } \\
\text { semua daerah } \\
\text { memperolehnya, } \\
\text { melainkan karena } \\
\text { adanya faktor-faktor } \\
\text { tertentu yang } \\
\text { menyebabkan daerah } \\
\text { tertentu } \\
\text { mendapatkannya, } \\
\text { seperti adanya gerakan } \\
\text { separatisme maupun } \\
\text { kekhususan warisan } \\
\text { kebudayaan secara } \\
\text { turun temurun }\end{array}$ \\
\hline 2. & Dasar hukum & $\begin{array}{l}\text { Undang-undang otonomi } \\
\text { daerah yaitu Undang-undang } \\
\text { Nomor } 23 \text { Tahun } 2014 \\
\text { Tentang Pemerintahan } \\
\text { Daerah yang mengatur } \\
\text { tentang kewenangan, hak, dan } \\
\text { kewajiban daerah }\end{array}$ & $\begin{array}{l}\text { Undang-undang } \\
\text { otonomi khusus yang } \\
\text { sesuai dengan daerah } \\
\text { tertentu, seperti } \\
\text { Undang-undang Nomor } \\
11 \text { Tahun } 2006 \text { Tentang } \\
\text { Pemerintahan Aceh }\end{array}$ \\
\hline 3. & Tujuan & $\begin{array}{l}\text { Memberikan kebebasan bagi } \\
\text { daerah sebagai bukti } \\
\text { pengamalan asas-asas } \\
\text { demokrasi melalui reformasi } \\
\text { pemerintahan }\end{array}$ & $\begin{array}{l}\text { Memberikan hak, } \\
\text { kewenangan dan } \\
\text { kewajiban bagi } \\
\text { terjaminnya sebuah } \\
\text { kekhususan yang } \\
\text { dimiliki oleh daerah }\end{array}$ \\
\hline
\end{tabular}

Sumber: disusun oleh penulis

Konflik separatisme Aceh telah menggagalkan sistem penyelenggaraan daerah karena tidak mampu mewujudkan kesejahteraan, keadilan dan kemajuan rakyat banyak khususnya memberikan perlindungan hak asasi manusia. Penderitaan dan kesengsaraan rakyat secara luas dirasakan sebagai dampak jangka panjang terjadinya konflik Aceh, sehingga perlu suatu upaya untuk mengembangkan dan menjalankan sistem 
pemerintahan berdasarkan prinsip-prinsip pemerintahan yang efektif dan efisien bagi kemajuan Aceh.

Konflik yang belum teratasi disusul dengan peristiwa gempa dan tsunami menjadi alasan kuat untuk kembali menumbuhkan dan membangun solidaritas seluruh kalangan bangsa Indonesia untuk membangun kembali masyarakat dan daerah Aceh. Hal ini kemudian menjadi dasar kesepakatan damai antara pemerintah pusat dan pemerintah Aceh yang dituangkan dalam Undnag-undang Nomor 11 Tahun 2006 Tentang Pemerintahan Aceh yang mengamalkan otonomi khusus dalam penyelenggaraan urusan daerah.

Otonomi khusus yang diberikan kepada Aceh merupakan gambaran keistimewaan Aceh sebagai daerah yang menerapkan syari'at Islam sebagai pedoman utama dari asas umum penyelenggaraan pemerintahan, hal ini menjadi ciri khas dalam mengamalkan sistem ketatanegaraan. Selain itu, pendirian partai politik lokal sebagai wadah ideologi rakyat Aceh menjadi jembatan baru bagi iklim pembangunan politik di Aceh.

Otonomi khusus mengandung arti hak, wewenang, dan kewajiban yang dimiliki suatu daerah ditentukan berbeda dengan daerah pada umumnya. Otonomi khusus berbeda dengan daerah khusus karena di dalam otonomi khusus perbedaan dengan daerah lain bukan hanya dari sisi struktur pemerintahan daerah, melainkan perbedaan ruang lingkup hak, wewenang, dan kewajiban yang dimiliki daerah, serta pola dan proporsi hubungan antara pemerintah pusat dengan daerah khusus (Malahayati, 2015: 23).

Kekhususan Aceh merupakan peluang berharga untuk melakukan berbagai penyesuaian dalam berbagai aspek yang terdiri dari struktur, susunan, pembentukan pemerintahan yang sesuai dengan jiwa dan semangat dalam berbangsa dan bernegara sesuai dengan nilai-nilai luhur dan pedoman hidup masyarakat Aceh yaitu syari'at Islam. Maka dari itu, pelaksanaan sebagian besar sistem pemerintahan daerah berpedoman kepada asas syari'at Islam.

Sisi kelembagaan di Aceh melatarbelakang pembentukan yang mengafiliasi hidupnya kembali lembaga adat dan lembaga syaria'at yang secara signifikan meredam permasalahan yang timbul dikalangan masyarakat pada saat itu. Pembentukan dan pendirian berbagai macam lembaga adat mulai dari tingkat gampong hingga provinsi menjadi tonggak utama dari pelaksanaan pembangunan kesejahteraan masyarakat Aceh.

Otonomi khusus bagi Aceh melahirkan berbagai macam harapan dan peluang bagi masyarakat Aceh untuk menumbuhkan kreatifitas, diskresi dan kebebasan dalam pelaksanaan sistem ketatanegaraan yang bertujuan menemukan kembali identitas diri sebagai masyarakat Aceh yang bernafaskan syari'at Islam serta membangun kembali Aceh paska keterpurukan akibat konflik dan tsunami.

Peluang positif dari otonomi khusus menjadi acuan dasar bagi masyarakat Aceh terhadap janji pemerintah pusat untuk melaksanakan asas desentralisasi secara utuh 
yang menjamin pelaksanaan otonomi yang seluas-luasnya bagi daerah serta menjamin tidak kembalinya sistem sentralistik seperti pada masa orde baru. Aceh sebagai daerah istimewa dan khusus dalam bidang agama, adat, pendidikan dan peran ulama telah mendapatkan peluang dan tantangan dalam mengimplementasikan keistimewaan dan kekhususannya tersebut, sehingga diperlukan komitmen yang kuat antara pemerintah pusat dan pemerintah Aceh bersama masyarakat Aceh untuk menjaga koridor otonomi ini dengan sebaik-baiknya.

\section{METODE PENELITIAN}

Penulisan ini akan membahas mengenai hubungan pemerintah pusat dan pemerintah Aceh mengenai persoalan otonomi khusus. Kajian permasalahan ini melingkupi penggunaan konsep desentralisasisebagai payung pelaksanaan otonomi khusus di Aceh dan otonomi khusus Aceh sebagai pondasi pemerintah Aceh dalam melaksanakan pembangunan yang setara dengan pemerintah pusat. Penulisan ini menggunakan tehnik pengumpulan data kepustakaan yaitu data penelitian diperoleh dari pengumpulan sumber bacaan meliputi buku, jurnal, surat kabar dan lain-lain.

Teknik analisa data dilakukan setelah penulis mendapatkan data melalui penelitian kepustakaan yang disusun, dianalisa, dan disajikan untuk mendapatkan gambaran yang sistematis tentang hubungan antara pemerintah pusat dengan pemerintah Aceh. Susunan data yang telah lengkap kemudian diekplorasi lebih mendalam untuk mendapatkan hasil penelitian dan menyimpulkan persoalan yang dikaji.

\section{PEMBAHASAN}

Keinginan kuat dari Pemerintah Aceh dalam membentuk qanun bendera dan lambang Aceh serta qanun Wali Nanggroe banyak menimbulkan berbagai isu dikalangan masyarakat dan pemerintah di Indonesia, hal ini menyebabkan hubungan antara pemerintah Aceh dan Pemerintah Pusat menjadi tegang sehingga menimbulkan berbagai dampak dalam beberapa aspek seperti aspek ekonomi, politik dan sosialbudaya di Aceh.

Perjanjian damai melalui MoU Helsinki seharusnya memberikan peluang bagi Aceh untuk mulai membenahi dirinya menjadi sebuah daerah yang lebih baik dalam berbagai tingkat pembangunan, baik ekonomi, politik serta sosial dan budaya. Salah satu isi perjanjian MoU Helsinki menyatakan bahwa Aceh diperbolehkan untuk mendirikan Partai Politik Lokal sebagai wadah untuk menampung ideologi kedaerahan Aceh, sehingga dibentuklah otonomi khusus di Aceh yang dituangkan dalam Undangundang Nomor 11 Tahun 2006 tentang Pemerintahan Aceh, atau disebut dengan Undang-undang Pemerintahan Aceh (UUPA). Namun, dalam implementasinya upaya perdamaian ini masih diuji dengan berbagai macam faktor seperti rasa sentimen. 
Pelaksanaan otonomi khusus di Aceh telah berjalan selama kurang lebih 7 tahun bermula dari pembentukan UUPA pada tahun 2006 hingga 2013 kini, dimana kekhususan Aceh sebagai daerah otonomi khusus salah satunya adalah hak untuk mendirikan partai politik lokal sebagai wadah untuk menampung aspirasi masyarakat Aceh yang memiliki ideologi kedaerahan yang sama dalam sebuah partai politik.

Kebebasan masyarakat Aceh untuk mendirikan partai politik lokal memberikan ruang yang besar bagi masyarakat Aceh untuk membangun sistem pemerintahan daerah Aceh yang lebih efektif dan efisien lagi. Hal ini dikarenakan masyarakat yang tergabung dalam sebuah partai politik lokal di Aceh yang kemudian dipilih menjadi wakil rakyat di Dewan perwakilan Rakyat Daerah (DPRD) maupun Dewan Perwakilan Rakyat Kabupaten/Kota (DPRK) dan Dewan Perwakilan Daerah (DPD) lebih mengetahui secara baik permasalahan yang ada di setiap daerah di Provinsi Aceh.

Dibandingkan dengan anggota Partai Nasional di Provinsi Aceh, Partai politik lokal di Aceh juga mendapatkan tempat di hati masyarakat Aceh di beberapa daerah kabupaten/kota. Salah satu besarnya dukungan masyarakat Aceh terhadap partai politik lokal ialah anggota partai politik lokal yang dipimpin oleh orang Aceh sendiri sehingga arah tujuan dari partai politik lokal tersebut akan langsung kepada kesejahteraan dan kemakmuran masyarakat Aceh, dibandingkan dengan partai nasional yang harus royal terlebih dahulu terhadap pemimpin yang ada dipusat.

Perjanjian damai Pemerintah Pusat dengan GAM yang melahirkan perjanjian MoU Helsinki, terdapat berbagai kewenangan yang harus diberikan pemerintah pusat untuk diatur sendiri oleh Aceh yang mengatur tentang sistem pemerintahan di Aceh, yaitu hukum mengenai pemerintahan Aceh, partisipasi politik, ekonomi dan aturan hukum. Peraturan tersebut menjadikan Aceh memiliki kuasa untuk membentuk partai politik lokal yang artinya memberikan kekuasaan yang lebih kepada Aceh dibandingkan dengan daerah-daerah lain di Indonesia.

Sejak perjanjian MoU Helsinki di Finlandia disepakati oleh Pemerintah Pusat dengan GAM dari tahun 2005 hingga 2018 ini banyak menimbulkan berbagai macam peristiwa, baik menyangkut masalah politik, ekonomi, sosial dan budaya. Dalam aspek politik, kursi parlemen Aceh yang banyak dikuasai oleh Partai Aceh sedikit mulai sedikit mulai menimbulkan kekhawatiran akibat pengajuan Rancangan Peraturan Daerah (di Aceh di sebut Rancangan Qanun) tentang bendera dan lambang Aceh yang memiliki simbol yang serupa dengan simbol gerakan seperatis GAM serta rancangan Qanun Wali Nanggroe (pemangku adat) yang banyak menimbulkan kontroversi baik dikalangan masyarakat luar Aceh maupun dalam masyarakat Aceh sendiri.

Pembahasan mengenai qanun bendera dan lambang Aceh serta qanun Wali Nanggroe menimbulkan berbagai polemik dikalangan masyarakat Aceh khususnya dan pemerintah Pusat pada umumnya. Hal ini dikarenakan simbol dari bendera dan lambang provinsi Aceh sangat mirip dengan bendera separatis GAM, serta lambang ini tidak mewakili seluruh suku-suku minoritas yang ada di Aceh seperti suku Gayo, Simeulu, 
Singkil, Subulussalam dan banyak lagi, sehingga terdapat banyak pertentangan dari suku minoritas, dan tidak semua suku Aceh itu sendiri mendukung qanun ini, karena dibalik qanun lambang bendera dan lambang Aceh tersebut banyak menimbulkan isu akan adanya pemisahan Aceh dari NKRI untuk menjadi sebuah negara sendiri.

Qanun Wali Nanggroe yaitu qanun yang akan menetapkan seorang pemangku adat di Provinsi Aceh, hal ini dianggap akan menimbulkan dualisme pemerintahan dikarenakan peran dari Wali Nanggroe ini adalah mengukuhkan parlemen Aceh dan Kepala Pemerintahan Aceh secara adat serta memberikan pandangan, arahan dan nasehat kepada eksekutif dan legislatif Aceh, hingga berhak untuk berpergian ke luar negeri dengan tujuan mengadakan kerja sama dengan negara-negara asing. Hak ini tentu akan mendominasi peran Wali Nanggroe melampaui peran yang dilakukan oleh eksekutif dan legislatif Aceh, yang mana kedudukan eksekutif dan legislatif adalah sama dan tidak bisa saling mengintervensi, namun kedudukan Wali Nanggroe dengan segala peran yang melekat padanya memberikan hak untuk dapat mengintervensi eksekutif, legislatif bahkan yudikatif di jajaran Pemerintah Aceh.

Keinginan yang kuat dari segelintir individu ataupun kelompok yang masih memiliki keinginan untuk melepaskan Aceh dari NKRI tentunya menimbulkan permasalahan dengan pemerintah pusat. Permasalahan yang ditimbulkan akibat adanya usulan membuat qanun bendera dan lambang Aceh serta qanun Wali Nanggroe tentu membuat hubungan Aceh dengan pemerintah pusat menjadi tegang, disatu pihak Aceh yang berpedoman kepada UUPA dan MoU Helsinki memang memiliki hak untuk melakukan hal itu semua, namun di lain pihak, yaitu Pemerintah Pusat sangat sulit untuk meloloskan qanun tersebut dikarenakan adanya isu bahwa Aceh akan sedikit demi sedikit memperjuangkan kemerdekaannya untuk lepas dari NKRI.

Kepemimpinan Aceh yang saat ini memang didominasi oleh orang-orang eks kombatan GAM lebih cenderung memperjuangkan hal-hal yang tidak mencakup kepentingan masyarakat Aceh secara umum, seharusnya DPRA harus mendahulukan qanun yang berkaitan langsung dengan masalah kesejahteraan masyarakat Aceh, seperti rancangan qanun tentang perpajakan, kesehatan dan pendidikan Aceh. Dominasi yang begitu besar dari pemerintah Aceh yang berpedoman kepada perjanjian MoU Helsinki dan UUPA memberikan jurang pemisah yang begitu besar dengan pemerintah pusat, hal ini tentu akan mempengaruhi kerja sama keduanya dalam sistem desentralisasi yang akan berdampak pada permasalahan politik, ekonomi dan sosial-budaya di Aceh.

Otonomi khusus di Aceh selama ini memberikan pengaruh yang cukup besar bagi Aceh, baik itu dari aspek ekonomi, politik dan sosial-budaya. Otonomi yang begitu khusus dan istimewa tersebut kepada Aceh dibandingkan dengan daerah provinsi lainnya di Indonesia memberikan contoh sistem otonomi yang perlu dikaji lebih jauh, melihat penerapan otonomi ini selama 13 tahun terakhir tentu memberikan berbagai dampak yang berbeda-beda dalam setiap aspek. Dampak ini juga akan berbeda pada tiap-tiap sasarannya, yaitu dampak terhadap masyarakat Aceh itu sendiri, masyarakat 
daerah yang lain di Indonesia serta dampak yang sangat besar kepada tiap-tiap unsurunsur pemerintahan yang terdapat di daerah-daerah lainnya di Indonesia.

Penyelenggaraan berbagai macam pelayanan publik di Aceh sudah menerapkan nilai-nilai khusus Aceh yang bercirikan syari'at Islam. Dalam sektor pendidikan, prinsip-prinsip pelaksanaan syari'at Islam sudah menajdi acuan dalam sistem pengajaran serta kurikulum pendidikan di Aceh. Sedangkan penyelenggaraan hukum adat juga dilaksanakan pada asas syari'at Islam meliputi aturan kehidupan adat, lembaga adat dan peran pemimpin adat dijaga serta dipertahankan.

Kesepakatan damai antara pemerintah pusat dengan pemerintah Aceh harus dipahami secara utuh sehingga arti penting perdamaian dapat dimengerti secara komprehensif, adil, permanen, bermartabat, dan damai secara berkesinambungan. Karena, implementasi dari kesepakatan damai harus dijaga oleh kedua belah pihak terutama niat baik, kesungguhan dan kepatuhan terhadap perjanjian damai yang telah disepakati.

\section{KESIMPULAN}

Otonomi khusus di Aceh menjadi jembatan yang menghubungkan kerjasama antara pemerintah pusat dengan pemerintah Aceh dalam upayanya membangun hubungan yang telah lama terputus. Keberadaan UUPA sebagai dasar hukum penegakkan otonomi khusus di Aceh telah memberi kepastian hukum bagi masyarakat Aceh untuk tetap menjaga persatuan dan kesatuan bangsa melalui nasionalisme di bawah payung NKRI. Segala kewenangan yang dimiliki pemerintah Aceh seperti pendirian partai lokal dan pelaksanaan syariat Islam di Aceh membuka lembaran baru bagi hubungan kedua-dua pemerintahan ini.

Kerjasama yang terbangun atas dasar tersebut telah membawa Aceh ke pentas panggung yang lebih besar untuk menunjukkan eksistensinya dalam sistem ketatanegaraan di Indonesia. Upaya dan usaha yang terus dibangun dan dibina oleh pemerintah pusat dan pemerintah Aceh sedikit demi sedikit mulai tampak memberi perubahan bagi masyarakat Aceh secara berkesinambungan. Hal ini tidak terlepas dari dampak positif yang terjadi setelah perjanjian damai disepakati demi kepentingan masyarakat banyak telah membawa perubahan bagi hubungan antara pemerintah pusat dan pemerintah Aceh, terutama berkenaan dengan stabilitas sistem politik yang dilandasakan kepada ideologi kedaerahan mampu diterima dan diamalkan dengan baik di Aceh sebagai tonggak pemerintahan melalui pelaksanaan otonomi khusus.

\section{DAFTAR PUSTAKA}

Amrizal J Prang. 2015. Pemerintahan Daerah: konteks otonomi simetris dan asimetris. Lhokseumawe: Biena Edukasi. 
Community: Volume 4, Nomor 2, Oktober 2018

ISSN: 2477-5746 e-ISSN: 2502-0544

Astim Riyanto. 2010. Teori Negara Kesatuan. Bandung: Yapemdo.

Bagir Manan. 2001. Menyongsong Fajar Otonomi Daerah. Yogyakarta: Universitas Islam Indonesia.

Darmansjah Djumala. 2013. Soft Power Untuk Aceh, Resolusi Konflik dan Politik Desentralisasi. Jakarta: Gramedia Pustaka Utama.

Haris, Syamsuddin (pnys). 2007. Desentralisasi dan Otonomi Daerah: Desentralisasi, Demokratisasi dan Akuntabilitas Pemerintahan Daerah. Jakarta: LIPI Press.

Malahayati. 2015. Otonomi Khusus dalam Sistem Pemerintahan Indonesia. Banda Aceh: Syiah Kuala.

Muhammad Fauzan. 2006. Hukum Pemerintahan Daerah Kajian Hubungan Keuangan Antara Pusat dan Daerah. Yogyakarta: UII Press.

Muhammad Noor. 2012. Memahami Desentralisasi Indonesia. Yogyakarta: Interpena.

Undang-undang Nomor 11 Tahun 2006 Tentang Pemerintahan Aceh

Undang-undang Nomor 23 Ta hun 2014 Tentang Pemerintahan Daerah 